\title{
Mandibular Third Molar Impaction: Review of Literature and a Proposal of a Classification
}

\author{
Gintaras Juodzbalys ${ }^{1}$, Povilas Daugela ${ }^{1}$ \\ ${ }^{1}$ Department of Maxillofacial Surgery, Lithuanian University of Health Sciences, Kaunas, Lithuania.
}

\author{
Corresponding Author: \\ Gintaras Juodzbalys \\ Vainiku 12 \\ LT- 46383, Kaunas \\ Lithuania \\ Phone: +37037297055 \\ Fax: +37037323153 \\ E-mail: gintaras@stilusoptimus.lt
}

\begin{abstract}
Objectives: The purpose of present article was to review impacted mandibular third molar aetiology, clinical anatomy, radiologic examination, surgical treatment and possible complications, as well as to create new mandibular third molar impaction and extraction difficulty degree classification based on anatomical and radiologic findings and literature review results.

Material and Methods: Literature was selected through a search of PubMed, Embase and Cochrane electronic databases. The keywords used for search were mandibular third molar, impacted mandibular third molar, inferior alveolar nerve injury third molar, lingual nerve injury third molar. The search was restricted to English language articles, published from 1976 to April 2013. Additionally, a manual search in the major anatomy and oral surgery journals and books was performed. The publications there selected by including clinical and human anatomy studies.

Results: In total 75 literature sources were obtained and reviewed. Impacted mandibular third molar aetiology, clinical anatomy, radiographic examination, surgical extraction of and possible complications, classifications and risk factors were discussed. New mandibular third molar impaction and extraction difficulty degree classification based on anatomical and radiologic findings and literature review results was proposed.

Conclusions: The classification proposed here based on anatomical and radiological impacted mandibular third molar features is promising to be a helpful tool for impacted tooth assessment as well as for planning for surgical operation. Further clinical studies should be conducted for new classification validation and reliability evaluation.
\end{abstract}

Keywords: tooth impacted; molar, third; alveolar nerve, inferior; lingual nerve injuries; mandibular canal; classification.

Accepted for publication: 11 June 2013

To cite this article:

Juodzbalys G, Daugela P. Mandibular Third Molar Impaction: Review of Literature and a Proposal of a Classification.

URL: http://www.ejomr.org/JOMR/archives/2013/2/e1/v4n2e1ht.pdf

doi: $10.5037 /$ jomr.2013.4201 


\section{INTRODUCTION}

In early 1954 Mead [1] has defined an impacted tooth as a tooth that is prevented from erupting into position because of malposition, lack of space, or other impediments. Later Peterson [2] , characterized impacted teeth as those teeth that fails to erupt into the dental arch within the expected time. In 2004 Farman [] $]$ wrote that impacted teeth are those teeth that prevented from eruption due to a physical barrier within the path of eruption.

According to Elsey and Rock [4] impaction of the third molar is occurring in up to $73 \%$ of young adults in Europe. Generally, third molars have been found to erupt between the ages of 17 and 21 years [ $[\underline{6}, \underline{6}]$. Furthermore, third molar eruption time have been reported to vary with races [5-8]. For example, mandibular third molars may erupt as early as 14 years of age in Nigerians [7], and up to the age of 26 years in Europeans [ $\underline{8}$ ]. The average age for the eruption of mandibular third molars in male is approximately 3 to 6 months ahead of females [9]. Most authors claim that the incidence of mandibular third molar impaction is higher in females $[\underline{8}, \underline{10}]$.

Third molar eruption and continuous positional changes after eruption can be related not only with race but also with nature of the diet, the intensity of the use of the masticatory apparatus and possibly due to genetic background [11].

Impaction of mandibular third molars is a common condition related with different difficulty degree of extraction operation and risk of complications, including iatrogenic trigeminal nerve injury. The purpose of present article was to review impacted mandibular third molar aetiology, clinical anatomy, radiologic examination, surgical treatment and possible complications, as well as to create new mandibular third molar impaction and extraction difficulty degree classification based on anatomical and radiologic findings and literature review results.

\section{MATERIAL AND METHODS}

Literature was selected through a search of PubMed, Embase and Cochrane electronic databases. The keywords used for search were mandibular third molar, impacted mandibular third molar, inferior alveolar nerve injury third molar, lingual nerve injury third molar. The search was restricted to English language articles, published from 1976 to April 2013. Additionally, a manual search in the major anatomy and oral surgery journals and books was performed.
The publications there selected by including clinical and human anatomy studies.

\section{RESULTS \\ Aetiology}

Many theories have been proposed owing to high incidence of mandibular third molar impaction. One of the most popular theory is insufficient development of the retromolar space $[\underline{12}, \underline{13}]$. Mandibular ramus growth is related to resorption at its anterior surface and deposition at its posterior surface, but in case of disbalance of this process, the mandibular third molars don't get enough space to erupt [14]. Proper mandibular third molars eruption also depends on their favourable path of eruption. For example, if the tooth bud is medially angulated during the initial stages of calcification and root development the path of eruption will be unfavourable [15]. However, impaction of mandibular third molars can develop due to a decrease in the angulation of the mandible and an increase in the angulation of the mandibular plane [16]. Yamaoka et al. [18] found the relation between the root angulation and impaction: angulated roots were more common in impacted mandibular third molars as compared to erupted mandibular third molars. Some authors indicates other important third molar impaction causes: malposition of the tooth germ, hereditary factors [19], lack of sufficient eruption force for third molars, and the theory of phylogenetic regression of the jaw size insufficient mesial movement of the dentition of modern human due to lack of interproximal attrition $[20,21]$.

\section{Clinical anatomy}

Mandibular third molar is situated at the distal end of the body of the mandible where is connection with relatively thin ramus. There is the region of weakness and the fracture can occur if excessive force will be applied during impacted wisdom tooth elevation without preliminary and adequate removing of surrounding bone [22]. The buccal alveolar bone in this region is thicker than the lingual. The external oblique ridge forms the buttress that reinforced the buccal plate. The lingual nerve often lies close to the cortical plate. There is high risk of lingual nerve damage using lingual split technique or elevating third molar flap medially to the distoangular recess [23]. Rood and Shehab [24] showed on panoramic radiographs that in most cases the roots of third molars are in close proximity to the mandibular canal. Furthermore, in some cases third molar roots can contact or penetrate into mandibular canal or they can be deflected. Close relationship of 
the canal with the roots can evoke inferior alveolar nerve damage during the surgery [22]

\section{Radiologic examination}

The location and configuration of impacted third molar, surrounding bone, mandibular canal and adjacent tooth are important in imaging diagnosis for the proper surgical operation planning. Periapical radiographs have been used for many years to assess the jaws during impacted teeth surgery. Long cone paralleling technique for taking periapical X-ray is the technique of choice for the following reasons: reduction of radiation dose; less magnification; a true relationship between the bone height and adjacent teeth is demonstrated [25]. One of the shortcomings of the present method is the use of film. Since the film is highly flexible, literally and figuratively, its processing can be suboptimal and it often leads poor image [26]. During the last decade, many dental practices replaced the film with digital imaging systems [28].

Nevertheless, the biggest concern of periapical radiographs is that mandibular canal could not be clearly identified in the third molar region. Furthermore, the angulation of the periapical film can affect the perceived location of the canal with respect to the bone crest [28]. When a specific region that is too large to be seen on a periapical view, panoramic radiograph can be the method of choice. The major advantages of panoramic images are the broad coverage of oral structures, low radiation exposure (about $10 \%$ of a full-mouth radiographs), and relatively inexpensive of the equipment. The major drawbacks of panoramic imaging are: lower image resolution, high distortion, and presence of phantom images. These can artificially produce apparent changes thus may hide some of important vital structures [12]. For example, cervical spine images often overlap on the anterior mandible. Furthermore, it depicts a twodimensional view of an intricate three-dimensional anatomic relationship and also fails to accurately project the buccolingual relation between the tooth and the inferior alveolar canal $[\underline{30}, \underline{31}]$.

Cone Beam Computed Tomography (CBCT) have been advocated as method of choice than there is need to have a three dimensional view of the mandibular third molar and adjacent anatomical structures [32,33]. Ghaeminia et al. [32] in prospective study evaluated the role of CBCT in the treatment of patients with impacted mandibular third molars $(\mathrm{n}=53)$ at increased risk of inferior alveolar nerve injury. After reviewing the CBCT images, significantly more subjects were reclassified to a lower risk for IAN injury compared with the panoramic radiograph assessments. This change in risk assessment also resulted in a significantly different surgical approach
$(\mathrm{P}<0.03)$. Authors concluded that $\mathrm{CBCT}$ contributes to optimal risk assessment and, as a consequence, to more adequate surgical planning, compared with panoramic radiography. It was reconfirmed by study of Matzen et al. [33], where CBCT influenced the treatment plan for $12 \%$ of cases. Direct contact in combination with narrowing of the canal lumen and canal positioned in a bending or a groove in the root complex observed in CBCT images were significant factors for deciding to change treatment plan.

\section{Indications for mandibular third molar extraction}

According to the recommendations of National Institute of Health (NIH) [34] both impacted and erupted mandibular third molars with evidence of follicular enlargement should be removed electively and that the associated soft tissue should be submitted for microscopic examination. Impacted teeth with pericoronitis should also be extracted electively because of their known potential for repetitive infection and morbidity. Furthermore, third molars with nonrestorable carious lesions and third molars contributing to resorption of adjacent teeth should be also extracted. Following indications for mandibular third molar extraction were highlighted by Koerner [35] : existing pathology or pain due to pericoronitis, periodontitis, periapical abscess, cysts or neoplasms, resorption of adjacent roots, and inflammation of the opposing soft tissue; aberrant positions in which the tooth is oriented buccally or lingually; preceding dental work with fixed or removable appliances; arch length discrepancy in cases when the impacted third molars are affecting the stability of orthodontic treatment. Lytle [20] added infection around the impaction; loss of bone around the impacted teeth; dental caries and damage of adjacent teeth; crowding of the dental arch; cysts and tumours associated with impacted teeth; pre-irradiation removal of impacted teeth; for prosthodontic reasons; and for chronic facial pain. The National Institute of Clinical Excellence (NICE) of England introduced guidelines relating to third molars surgery. These recommended against the prophylactic removal of third molars and listed specific clinical indications for surgery.

\section{Surgical extraction of impacted mandibular third molar and possible complications}

There are two main intraoral approaches for surgical removal of impacted mandibular third molars: one through the sublingual space and the other buccally through the entire mandibular thickness. There is also extraoral method from the submandibular space [36-38]. Sublingual access requires incision 
and elevation of a wide mucoperiosteal intrasulcular flap on the lingual side of the mandible, in the molar and premolar regions. Dissection of the mylohyoid muscle attachment is necessary to reach the impacted molar. The buccal approach requires the elevation of a wide mucoperiosteal flap localized around the molar-premolar region. An extensive osteotomy is made underneath the apical area of the mandibular teeth. However there are many modifications of flap techniques, including envelope flap, two sided flap, and coma shaped flap [39]. In every case the third molar flap should provide adequate visualisation of the surgical field.

After mucoperiosteal flap elevation excessive bone must be excised using bur before third molar extraction. In most cases there will be necessary to remove buccal and distal bone borders. In difficult cases the tooth should be sectioned with a fissure bur in a highspeed handpiece. The wound should be irrigated with cool sterile physiologic saline solution. After tooth extraction using elevator or forceps it is necessary to clean operation area and to suture the wound without tension [누].

The frequency and severity of untoward events associated with surgical procedures are influenced by multiple factors that may be related to the procedure, patient, and/or surgeon [41]. Complications related to mandibular third molar extraction can be classified to intraoperative and postoperative [2]. Intraoperative complications are as follows: mandibular fracture, damage of adjacent teeth, tooth or tooth fragments displacement into soft tissues and bleeding. In cases if the excessive intraoral force was applied or/and part of bone was removed, risk of mandibular fracture or damage of adjacent teeth is increased $[\underline{2}, \underline{40}]$. Tooth or tooth fragments displacement into soft tissues can occur in case of wrong operation technique [41].

The most serious and unpleasant iatrogenic complication that arise from third molar surgery is inferior alveolar and/or lingual nerve injury and neurosensory function disturbance. The incidence of inferior alveolar nerve injury according to different authors varies from $0.81 \%$ to $22 \%$ of cases [42-47]. $1 \%$ to $4 \%$ of patients are at risk of permanent injury [48]. Lingual nerve injury incidence was reported between $0.4 \%$ and $25 \%$ [49-53]. Inferior alveolar nerve injury can cause paresthesia to complete numbness and/or pain [54] in the region of the skin of the mental area, the lower lip, mucous membranes, and the gingiva as far posteriorly as the second premolar [55]. Furthermore this commonly interferes with speech, eating, kissing, make-up application, shaving and drinking [56]. The injury of the lingual nerve leads to numbness of the ipsilateral anterior two thirds of the tongue and taste disturbance [50].
Typical postoperative complications are pain, swelling, bruising, trismus [57], osteitis and surgical site infection [58].

\section{Classifications and risk factors identification}

In order to minimise number of complications during mandibular third molar extraction several classifications have been developed that are assessing the difficulty of surgical procedure and helping to create an optimal treatment plan. The most popular are Winter's [59] and Pell and Gregory's [60] systems who are classifying the inclinations and positions of the third molars based on the relation among the dental longitudinal axis, occlusal plane and ascending mandibular ramus. These systems have been extensively adopted and applied in clinical practice. However some authors claim that these scales have little value for predicting the degree of extraction difficulty, [61] mainly because these systems of classification introduce error of interpretation by the observer [62]. Later Peterson [2] proposed a modification of the Pell and Gregory scale that included a third factor, the angulation of the molar (mesio-angular, horizontal, vertical or disto-angular). Clinical studies showed that there is no doubt about the importance of individual parameters of mentioned above classifications. Chuang et al. [58] demonstrated in their study that the level of impaction is associated with an increased risk of inflammatory complications following third molar surgery. Carvalho and Vasconcelos [63] extracted 473 mandibular third molars for 285 patients and concluded that root number $(\mathrm{P}<0.004$ and morphology $(\mathrm{P}<0.031)$, tooth position $(\mathrm{P}=0.001)$, periodontal space $(\mathrm{P}<0.004)$ and second molar relation $(\mathrm{P}=0.001)$ were significant predictors of surgical difficulty. Authors mentioned that not all significant predictors of surgical difficulty should be considered indicators of complications. Akadiri and Obiechina [64] demonstrated in their study wisdom tooth depth angulation and root morphology as the most consistent determinants of extraction difficulty.

Eruption status of the lower third molar is important risk factor for inferior alveolar nerve injury. Incidences of inferior alveolar nerve injury in fully erupted, partially erupted and unerupted lower wisdom teeth were $0.3 \%$, $0.7 \%$ and $3.0 \%$, respectively $[65,66]$. The risk of nerve injury is increasing with the depth of the impacted mandibular wisdom teeth $[\underline{23}, 66]$. It was demonstrated the relationship between pattern of impaction and inferior alveolar nerve injury. The incidence of nerve injury was highest in horizontally impacted lower wisdom teeth $(1.7 \%)$, followed by distal impaction $(1.4 \%)$, mesial impaction (1.3\%) and vertical impaction $(1.1 \%)[\underline{23}, \underline{65}, \underline{66}]$.

In general the proximity of the mandibular third molar to the mandibular canal is considered a risk 
factor for damage to the inferior alveolar nerve. This fact inspirited further studies for the predictive radiographic parameters identification. Rood and Shehab [24] distinguished four radiographic indicators observed in the tooth root (darkening, deflection and narrowing of the root, and a bifid root apex), and the other three in the canal (diversion, narrowing, and interruption in the white line of the canal). Studies demonstrated that the most important parameters for inferior alveolar nerve injury prediction are third molar root apices inside or in contact with the mandibular canal $[\underline{46}, \underline{67-69}]$. Furthermore, the prevalence of post-extraction complications correlated with the absence of cortication around the mandibular canal. It was reconfirmed by Park et al. [70] in their retrospective cohort study (179 patients and 259 teeth) where the overall prevalence of paresthesia was $4.2 \%$. In contrast, the prevalence of paresthesia in group involving an interrupted mandibular canal cortex was $11.8 \%$. Ueda et al. [71] performed similar study (99 patients and 145 teeth) and showed that inferior alveolar nerve injury was observed in 7 of 145 cases $(4.8 \%)$ ). All 7 cases exhibited absence of cortication. Leung and Cheung [72] in literature review demonstrated that $16.2 \%$ of the surgery with the inferior alveolar nerve exposed developed postoperative inferior alveolar nerve deficit, whilst only $1.1 \%$ of the surgeries without nerve exposure developed inferior alveolar nerve deficit
$(\mathrm{P}<0.0001)$. The risk ratio of inferior alveolar nerve injury from intraoperative nerve exposure is 14.9 times more likely than if the nerve is not exposed.

Iatrogenic injury to the lingual nerve may happen during third molar surgery due to the anatomical proximity of the cortex region of the molar to the nerve, being separated from it by the periosteum alone [52]. Surgery on unerupted mandibular third molars was at higher risk (5.8\%) of lingual nerve injury compared with erupted $(0.3 \%)$ or partially erupted $(2.0 \%)$ teeth $(\mathrm{P}<0.0001)[\underline{66}, \underline{73}]$. The incidence of lingual nerve injury was highest in distally impacted lower wisdom teeth $(4.0 \%, \mathrm{P}<0.01)$, followed by horizontal impaction $(2.8 \%)$, mesial impaction (2.4\%) and vertical impaction $(1.9 \%)[23,46,66]$. The risk ratio of lingual nerve injury was 1.94 times more likely to occur if the lingual flap was raised than if it was not and 4.1 times more likely to occur if the lingual split technique was used in comparison with the buccal approach [72].

\section{Mandibular third molar impaction classification based on anatomical and radiologic features}

New mandibular third molar impaction and extraction difficulty degree classification based on anatomical and radiologic findings and literature review results is suggested (Table 1).

Table 1. Mandibular third molar impaction classification

\begin{tabular}{|c|c|c|c|c|}
\hline \multirow{2}{*}{$\begin{array}{c}\text { Position of the } \\
\text { mandibular third molar }\end{array}$} & \multicolumn{4}{|c|}{ Risk degree of presumptive intervention (score) } \\
\hline & Conventional (0) & Simple (1) & Moderate (2) & Complicated (3) \\
\hline \multicolumn{5}{|c|}{ Mesiodistal position in relation to the second molar $-M$ and the mandibular ramus $-\mathrm{R}$} \\
\hline $\begin{array}{l}\text { Relation to the second } \\
\text { molar - M }\end{array}$ & $\begin{array}{c}\text { Crown directed at or } \\
\text { above the equator of } \\
\text { the second molar }\end{array}$ & $\begin{array}{l}\text { Crown directed below the } \\
\text { equator to the coronal third } \\
\text { of the second molar root }\end{array}$ & \begin{tabular}{|c|}
$\begin{array}{c}\text { Crown/roots directed to } \\
\text { the middle third of the } \\
\text { second molar root }\end{array}$ \\
\end{tabular} & $\begin{array}{l}\text { Crown/roots directed to the } \\
\text { apical third of the second } \\
\text { molar root }\end{array}$ \\
\hline $\begin{array}{l}\text { Relation to the } \\
\text { mandibular ramus }-\mathbf{R}\end{array}$ & $\begin{array}{c}\text { Sufficient space in the } \\
\text { dental arch }\end{array}$ & $\begin{array}{l}\text { Partially impacted in the } \\
\text { ramus }\end{array}$ & $\begin{array}{c}\text { Completely impacted in } \\
\text { the ramus }\end{array}$ & $\begin{array}{l}\text { Completely impacted in the } \\
\text { ramus in distoangular or } \\
\text { horizontal position }\end{array}$ \\
\hline \multicolumn{5}{|c|}{ Apicocoronal position in relation to the alveolar crest $-\mathrm{A}$ and the mandibular canal $-\mathrm{C}$ (IAN injury risk) } \\
\hline $\begin{array}{l}\text { Relation to the adjacent } \\
\text { alveolar crest (from the } \\
\text { uppermost point of the } \\
\text { tooth) - A }\end{array}$ & $\begin{array}{l}\text { Tooth is completely } \\
\text { erupted }\end{array}$ & $\begin{array}{l}\text { Partially impacted, but } \\
\text { widest part of the crown } \\
\text { (equator) is above the bone }\end{array}$ & $\begin{array}{c}\text { Partially impacted, but } \\
\text { widest part of the crown } \\
\text { (equator) is below the } \\
\text { bone }\end{array}$ & $\begin{array}{c}\text { Completely encased in the } \\
\text { bone }\end{array}$ \\
\hline $\begin{array}{c}\text { Relation to the } \\
\text { mandibular canal (from } \\
\text { the lowermost point of the } \\
\text { tooth) - C }\end{array}$ & $\begin{array}{l}\geq 3 \mathrm{~mm} \text { to the } \\
\text { mandibular canal }\end{array}$ & $\begin{array}{l}\text { Contacting or penetrating } \\
\text { the mandibular canal, wall } \\
\text { of the mandibular canal } \\
\text { may be identified }\end{array}$ & \begin{tabular}{|c|} 
Contacting or \\
penetrating the \\
mandibular canal, wall \\
of the mandibular canal \\
is unidentified
\end{tabular} & $\begin{array}{l}\text { Roots surrounding the } \\
\text { mandibular canal }\end{array}$ \\
\hline \multicolumn{5}{|c|}{ Buccolingual position in relation to mandibular lingual and buccal walls - B (LN injury risk) } \\
\hline $\begin{array}{c}\text { Relation to mandibular } \\
\text { lingual and buccal } \\
\text { walls - B }\end{array}$ & Closer to buccal wall & $\begin{array}{l}\text { In the middle between } \\
\text { lingual and buccal walls }\end{array}$ & Closer to lingual wall & $\begin{array}{c}\text { Closer to lingual wall, when } \\
\text { the tooth is partially impacted } \\
\text { or completely encased in the } \\
\text { bone (A2 or A3) }\end{array}$ \\
\hline \multicolumn{5}{|c|}{ Spatial position - S } \\
\hline Spatial position - S & Vertical $\left(90^{\circ}\right)$ & Mesioangular $\leq 60^{\circ}$ & Distoangular $\geq 120^{\circ}$ & $\begin{array}{l}\text { Horizontal }\left(0^{\circ}\right) \text { or inverted } \\
\left(270^{\circ}\right)\end{array}$ \\
\hline
\end{tabular}

$\mathrm{IAN}=$ inferior alveolar nerve; $\mathrm{LN}=$ lingual nerve. 
Classification of mandibular third molar impaction and extraction difficulty degree enables the clinician to determine the difficulty in removal of the impacted tooth, to choose optimal treatment and to avoid the majority of possible complications. This classification describes wisdom tooth relation to the adjacent anatomical structures: mandibular ramus, second molar, alveolar crest, mandibular canal, and the spatial position of the tooth. Wisdom tooth position assessment should be performed clinically and using CBCT and panoramic radiographic images. The tooth position according to the all aforementioned landmarks has been not completely classified yet. Proposed classification is determining mandibular third molar mesiodistal position (in relation to the second molar - M and the mandibular ramus - R), apicocoronal position (in relation to the alveolar crest $\mathrm{A}$, and the mandibular canal - C), buccolingual position (in relation to mandibular lingual and buccal walls - B) and spatial tooth position - S.

Risk degree of presumptive intervention is scored as follows:

- conventional extraction is determined, when all parameters are equal to score 0 ;

- simple, when at least one parameter is equal to score 1 and surgical extraction with coronectomy and/or sectioning of roots is determined;

- moderate, when at least one parameter is equal to score 2 and surgical extraction with coronectomy and/or sectioning of roots is determined;

- complicated, when at least one parameter is equal to score 3 and surgical extraction with coronectomy and/or sectioning of roots is determined. Extraoral approach can be indicated.

To make the classification more informative, each component of the indices (M,R,A,C,B and $\mathrm{S}$ ) is described independently. For example, position, extraction difficulty degree of tooth 48 and risk of trigeminal nerve damage during surgery is described as following: M1,R1,A2,C2,B1,S3 (Figure 1A, B). This description determines complicated extraction, because one of the parameters $-\mathrm{S}$ is equal to 3. Detailed explanation: crown is in contact below the equator to the coronal third of the second molar (M1), partially impacted in the ramus (R1), widest part of the crown (equator) is below the bone (A2), roots are contacting or penetrating the mandibular canal, wall of the mandibular canal is unidentified (C2), tooth is located in the middle between lingual and buccal walls (B1); horizontal spatial position (S3). Complicated extraction is anticipated and $\mathrm{C} 2$ value presumes moderate risk of inferior alveolar nerve damage.

There are some new approaches in assessing different anatomical and radiological parameters in the present classification. For example, the depth of tooth impaction in Pell and Gregory's [60] classification was assessed according to the occlusal plane, but in some cases the crown of wisdom tooth is small in size and located below occlusal plane. However the tooth can be completely erupted and easily extracted. The assessment of tooth impaction (coronal position) should be evaluated from the alveolar crest, because the extraction difficulty is determined predominantly by the depth of impaction in the bone. Furthermore, it is necessary to highlight the lower landmark of the possible apicocoronal wisdom tooth position which is determined by mandibular canal. It was mentioned above that the proximity of the mandibular third molar to the mandibular canal is considered a risk factor for damage to the inferior alveolar nerve. In contrast, some previous classifications recommended assessing too many radiological parameters determining wisdom tooth roots relationship with mandibular canal. For example, Rood and Shehab [24] distinguished four radiographic indicators observed in the tooth

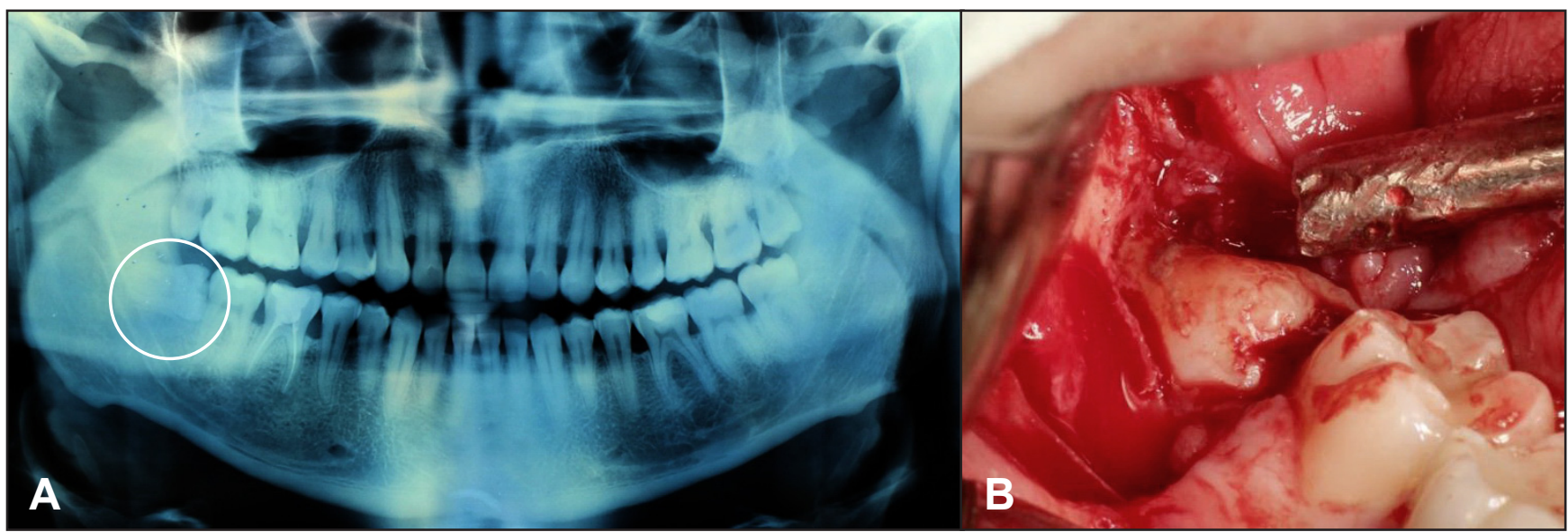

Figure 1. A = Tooth No. 48 is classified as M1,R1,A2,C2,B1,S3 on the ortopantomograph

$\mathrm{B}=$ Impaction in horizontal spatial position index (S3) predicts complicated surgical extraction. 
root (darkening, deflection and narrowing of the root, and a bifid root apex), and the other three in the canal (diversion, narrowing, and interruption in the white line of the canal). Latest clinical studies demonstrated that the most important parameters for inferior alveolar nerve injury prediction are third molar root apices inside or in contact with the inferior alveolar canal $[46,67-69]$ and absence of cortication around the inferior alveolar canal [70-72], this is why mentioned above parameters were included into inferior alveolar nerve injury risk evaluation assessment. In such cases clinicians should avoid apical pressure during root elevation or even to perform multiple sectioning of the tooth to reduce any stress to a root on elevation. CBCT scan should be also accomplished for detailed surgery planning in cases when $\mathrm{C} 2$ or $\mathrm{C} 3$ relation to the mandibular canal is expected on two-dimensional radiographs (Figure 2A, B). Some authors are recommending to perform coronectomy of impacted wisdom tooth if roots are surrounding the mandibular canal because there is high risk or inferior alveolar nerve injury $[\underline{33}, \underline{74}, \underline{75}]$. In contrast, it was considered that in cases when wisdom tooth position is $\geq 3 \mathrm{~mm}$ away from the mandibular canal, there is no risk to damage mandibular canal during surgical extraction (Figure 3).

Mesiodistal position is defined in relation to the second molar and the mandibular ramus. It is important to assess impacted tooth relationship to the second molar in order to avoid iatrogenic tooth traumatisation. The impaction degree of mandibular third molar in the ramus of mandible is associated with extraction operation difficulty score and postoperative complications manifestation. For example, high risk degree is registered when tooth is completely impacted in the mandibular ramus in distoangular or horizontal position (Figure 4).

Buccolingual third molar position in relation to mandibular lingual and buccal walls is reflecting risk of lingual nerve injury. It was discussed previously that iatrogenic injury to the lingual nerve may happen during

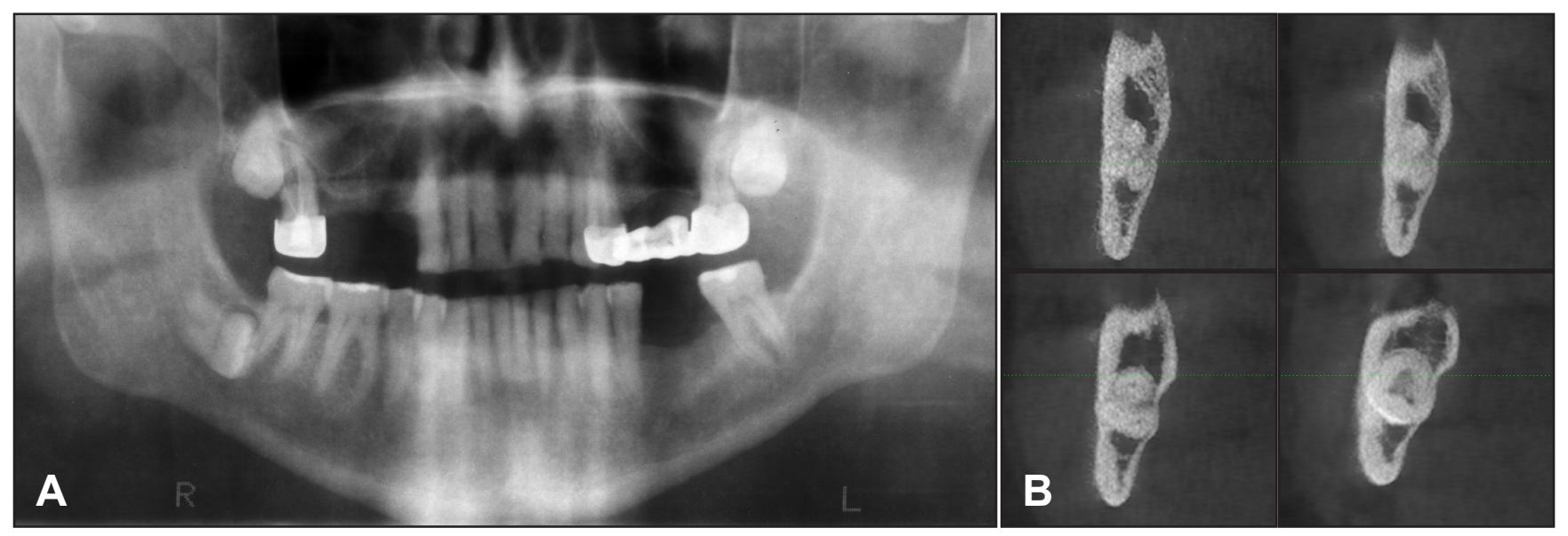

Figure 2. $\mathrm{A}=$ On orthopantomograph close contact between impacted right mandibular third molar and mandibular canal is suspected. $\mathrm{B}=$ More detailed view on the $\mathrm{CBCT}$ images reveals tooth penetration through the mandibular canal wall (C2) and moderate risk of inferior alveolar nerve damage.

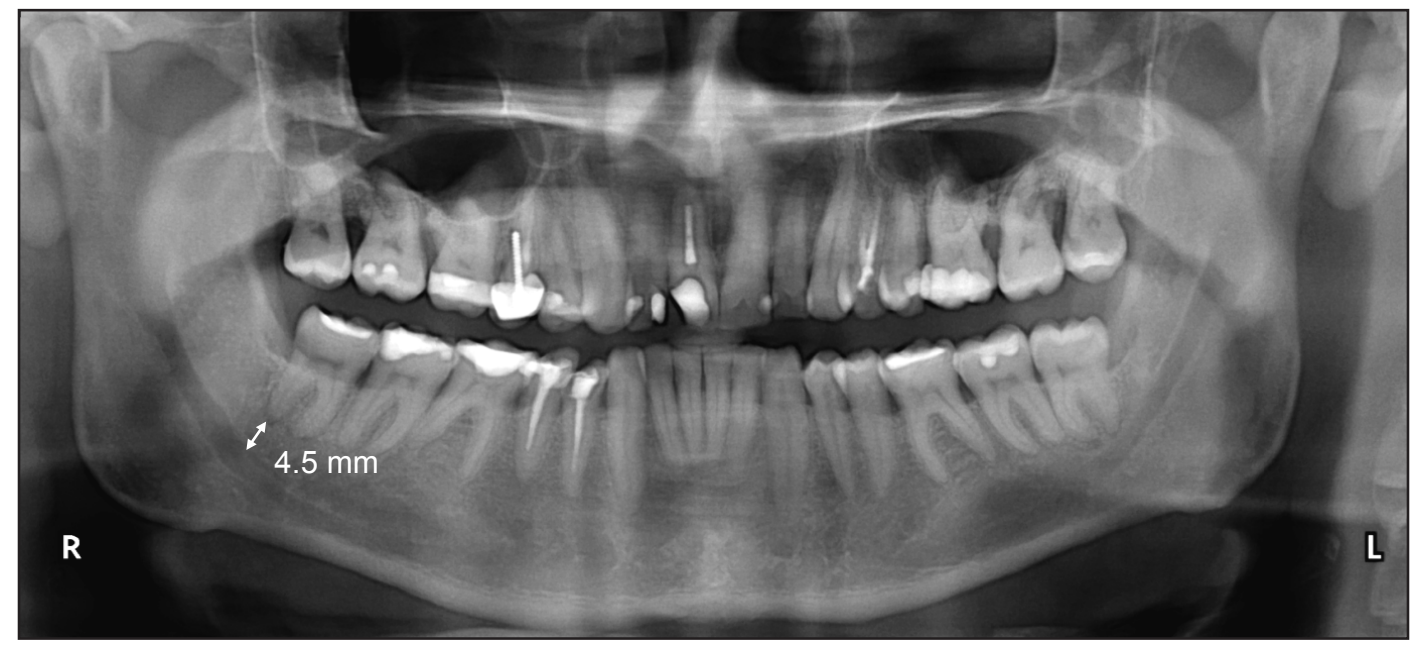

Figure 3. Roots of tooth No. 48 are $\geq 3 \mathrm{~mm}$ away from the mandibular canal (C0) on the orthopantomograph. There is no risk to damage inferior alveolar nerve during surgical extraction. 


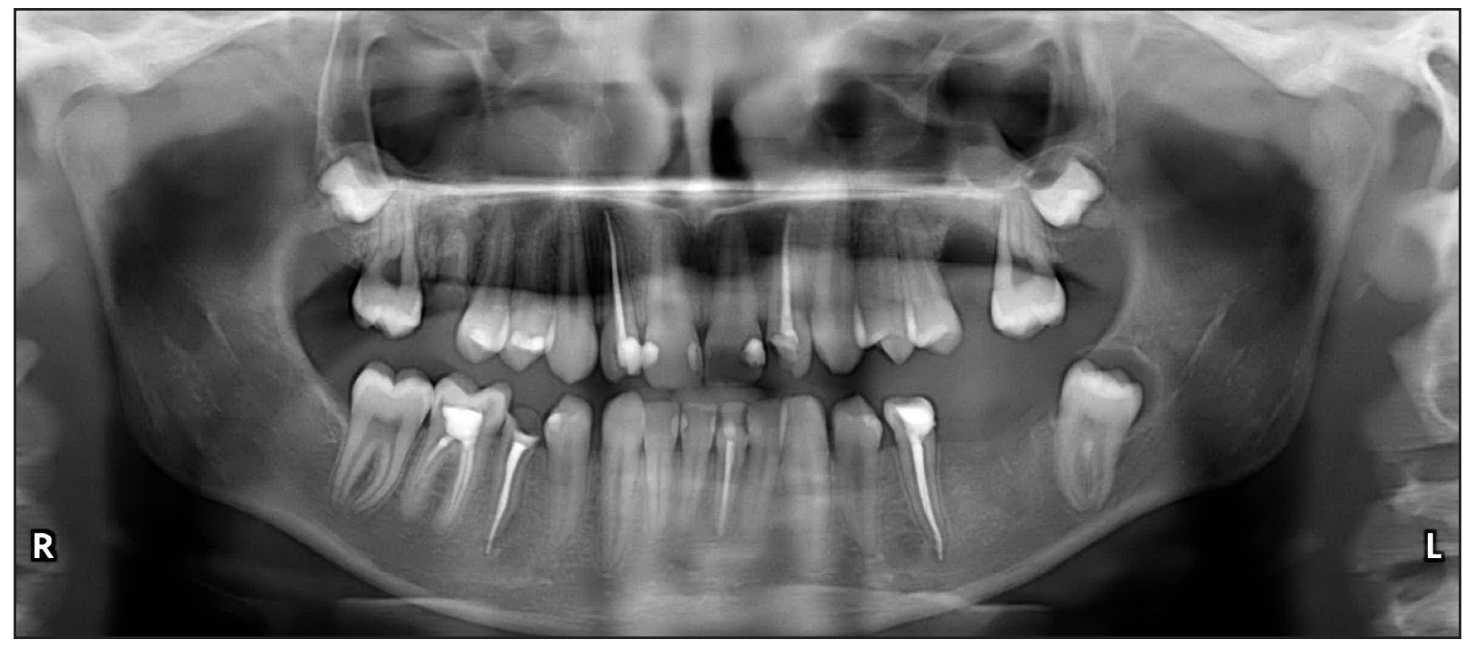

Figure 4. Tooth No. 38, completely impacted in the mandibular ramus in distoangular position and classified as A3 and R3 according to the relation to alveolar crest and mandibular ramus, is noticed on the orthopantomograph. Complicated surgical extraction is anticipated..

third molar surgery due to the anatomical proximity of the cortex region of the molar to the nerve [52]. Surgery on unerupted mandibular third molars was at higher risk $(5.8 \%)$ of lingual nerve injury compared with erupted $(0.3 \%)$ or partially erupted $(2.0 \%)$ teeth $(\mathrm{P}<0.0001)[66,73]$. Thus the highest risk of lingual nerve injury was scored in case when the tooth is partially impacted or completely encased in the bone (A2 or A3) and is located closer to the lingual wall. Spatial mandibular third molar position is reflecting extraction difficulty degree especially in combination with other indices. For example distoangular or horizontal impacted tooth position in combination with deep impaction in the mandibular ramus, can be complicated case even for experienced clinician.

\section{CONCLUSIONS}

There are selected only the most informative parameters in presented herein classification, because it is impossible to reflect all important parameters, such as periodontal ligament width, soft tissue condition, patient characteristic, clinician's experience, and et cetera in one classification which should be useful in daily practice. The classification proposed here based on anatomical and radiological impacted mandibular third molar features is promising to be a helpful tool for impacted tooth assessment as well as for planning for surgical operation. Further clinical studies should be conducted for new classification validation and reliability evaluation.

\section{AKNOWLEDGEMENT AND DISCLOSURE STATEMENTS}

The authors report no conflict of interest related to the present study.

\section{REFERENCES}

1. Archer WH. Oral Surgery: A Step-By-Step Atlas of Operative Techniques, 4th ed. Philadelphia: W.B. Saunders Company; 1966. p. 507-10.

2. Peterson LJ. Principles of Management of Impacted Teeth. In: Peterson LJ, Ellis E III, Hupp JR, Tuker MR, editors. Contemporary Oral and Maxillofacial Surgery, 3rd ed. St. Louis: Mosby; 1998. p. 215-48.

3. Agarwal KN, Gupta R, Faridi MM, Kalra N. Permanent dentition in Delhi boys of age 5-14 years. Indian Pediatr. 2004 Oct;41(10):1031-5. [Medline: 15523129]

4. Khan NB, Chohan AN, AlMograbi B, AlDeyab S, Zahid T, AlMoutairi M. Eruption Time of Permanent First Molars and Incisors Among a Sample of Saudi Male Schoolchildren. Saudi Dent J. 2006 Jan-Apr;18(1):18-24.

5. Elsey MJ, Rock WP. Influence of orthodontic treatment on development of third molars. Br J Oral Maxillofac Surg. 2000 Aug;38(4):350-3. [Medline: 10922167] [doi: 10.1054/bjom.2000.0307]

6. Pahkala R, Pahkala A, Laine T. Eruption pattern of permanent teeth in a rural community in northeastern Finland. Acta Odontol Scand. 1991 Dec;49(6):341-9. [Medline: 1776401] [doi: 10.3109/00016359109005930]

7. Odusanya SA, Abayomi IO. Third molar eruption among rural Nigerians. Oral Surg Oral Med Oral Pathol. 1991 Feb;71(2):151-4. [Medline: 2003009] [doi: 10.1016/0030-4220(91)90457-N] 
8. Kruger E, Thomson WM, Konthasinghe P. Third molar outcomes from age 18 to 26: findings from a populationbased New Zealand longitudinal study. Oral Surg Oral Med Oral Pathol Oral Radiol Endod. 2001 Aug;92(2):150-5. [Medline: 11505260] [doi: 10.1067/moe.2001.115461]

9. Hattab FN, Alhaija ES. Radiographic evaluation of mandibular third molar eruption space. Oral Surg Oral Med Oral Pathol Oral Radiol Endod. 1999 Sep;88(3):285-91. [Medline: 10503855] [doi: 10.1016/S1079-2104(99)70029-6]

10. Yuasa H, Sugiura M. Clinical postoperative findings after removal of impacted mandibular third molars: prediction of postoperative facial swelling and painbased on preoperative variables. Br J Oral Maxillofac Surg. 2004 Jun;42(3):209-14. [Medline: 15121265] [doi: 10.1016/j.bjoms.2004.02.005]

11. Alling CC, Alling RD. Indications for management of impacted teeth. In: Alling CC, Helfrick JF, Alling RD, editors. Impacted Teeth. Philadelphia: W.B. Saunders; 1993. p. 49-54.

12. Bishara SE, Andreasen G. Third molars: a review. Am J Orthod. 1983 Feb;83(2):131-7. [Medline: 6572040] [doi: 10.1016/S0002-9416(83)90298-1]

13. Grover PS, Lorton L. The incidence of unerupted permanent teeth and related clinical cases. Oral Surg Oral Med Oral Pathol. 1985 Apr;59(4):420-5. [Medline: 3858781] [doi: 10.1016/0030-4220(85)90070-2]

14. Björk A. Prediction of mandibular growth rotation. Am J Orthod 1969;55:585-99. [doi: 10.1016/0002-9416(69)90036-0]

15. Richardson M. Changes in lower third molar position in the young adult. Am J Orthod Dentofacial Orthop. 1992 Oct;102(4):320-7. [Medline: 1456216] [doi: 10.1016/0889-5406(92)70047-E]

16. Richardson M. The development of third molar impaction. Br J Orthod. 1975 Oct;2(4):231-4. [Medline: 1065361]

17. Odusanya SA. Third molar impaction among Nigerian youths. Odontostomatol Trop. 1984 Jun;7(2):79-83. [Medline: 6593696]

18. Yamaoka M, Tambo A, Furusawa K. Incidence of inflammation in completely impacted lower third molars. Aust Dent J. 1997 Jun;42(3):153-5. [Medline: 9241923] [doi: 10.1111/j.1834-7819.1997.tb00112.x]

19. Peck S, Peck L, Kataja M. Concomitant occurrence of canine malposition and tooth agenesis: evidence of orofacial genetic fields. Am J Orthod Dentofacial Orthop. 2002 Dec;122(6):657-60. [Medline: 12490878] [doi: 10.1067/mod.2002.129915]

20. Bermúdez de Castro JM. Third molar agenesis in human prehistoric populations of the Canary Islands. Am J Phys Anthropol. 1989 Jun;79(2):207-15. [Medline 2662782]

21. Lytle JJ. Etiology and indications for the management of impacted teeth. Northwest Dent. 1995 Nov-Dec;74(6):23-32. [Medline: 9462087$]$

22. Kay LW, Killey HC. The extraction of teeth. The impacted third molar. Dent Update. 1976 Mar-Apr;3(2):49-52. [Medline: 1074729]

23. Blondeau F, Daniel NG. Extraction of impacted mandibular third molars: postoperative complications and their risk factors. J Can Dent Assoc. 2007 May;73(4):325. [Medline: 17484797] [FREE Full Text]

24. Rood JP, Shehab BA. The radiological prediction of inferior alveolar nerve injury during third molar surgery. Br J Oral Maxillofac Surg. 1990 Feb;28(1):20-5. [Medline: 2322523] [doi: 10.1016/0266-4356(90)90005-6]

25. Denio D, Torabinejad M, Bakland LK. Anatomical relationship of the mandibular canal to its surrounding structures in mature mandibles. J Endod. 1992 Apr;18(4):161-5. [Medline: 1402570] [doi: 10.1016/S0099-2399(06)81411-1]

26. van der Stelt PF. Filmless imaging: the uses of digital radiography in dental practice. J Am Dent Assoc. 2005 Oct;136(10):1379-87. [Medline: 16255462]

27. Kim IS, Kim SG, Kim YK, Kim JD. Position of the mental foramen in a Korean population: a clinical and radiographic study. Implant Dent. 2006 Dec;15(4):404-11. [Medline: 17172959] [doi: 10.1097/01.id.0000243319.66845.15]

28. Misch CE. Diagnostic imaging techniques. In: Misch CE, editors. Contemporary Implant Dentistry, 3rd ed. St Louis: CV Mosby Company; 2008. p. 38-67.

29. White SC, Heslop EW, Hollender LG, Mosier KM, Ruprecht A, Shrout MK; American Academy of Oral and Maxillofacial Radiology, ad hoc Committee on Parameters of Care. Parameters of radiologic care: An official report of the American Academy of Oral and Maxillofacial Radiology. Oral Surg Oral Med Oral Pathol Oral Radiol Endod. 2001 May;91(5):498511. [Medline: 11346726$]$ [doi: $10.1067 /$ moe.2001.114380]

30. Khan I, Halli R, Gadre P, Gadre KS. Correlation of panoramic radiographs and spiral CT scan in the preoperative assessment of intimacy of the inferior alveolar canal to impacted mandibular third molars. J Craniofac Surg. 2011 Mar;22(2):566-70. [Medline: 21403569] [doi: 10.1097/SCS.0b013e3182077ac4]

31. Juodzbalys G, Wang HL. Guidelines for the Identification of the Mandibular Vital Structures: Practical Clinical Applications of Anatomy and Radiological Examination Methods. J Oral Maxillofac Res 2010;1(2):e1. URL: http://www.ejomr.org/JOMR/archives/2010/2/e1/e1ht.htm [doi: 10.5037/jomr.2010.1201]

32. Ghaeminia H, Meijer GJ, Soehardi A, Borstlap WA, Mulder J, Vlijmen OJ, Bergé SJ, Maal TJ. The use of cone beam CT for the removal of wisdom teeth changes the surgical approach compared with panoramic radiography: a pilot study. Int J Oral Maxillofac Surg. 2011 Aug;40(8):834-9.Epub 2011 Apr 19. [Medline: 21507612] [doi: 10.1016/j.ijom.2011.02.032]

33. Matzen LH, Christensen J, Hintze H, Schou S, Wenzel A. Influence of cone beam CT on treatment plan before surgical intervention of mandibular third molars and impact of radiographic factors on deciding on coronectomy vs surgical removal. Dentomaxillofac Radiol. 2013;42(1):98870341.Epub 2012 Aug 29. [Medline: 22933533] [doi: $10.1259 / \mathrm{dmfr} / 98870341]$ 
34. Removal of third molars. Sponsored by the National Institute of Dental Research, November 28-30, 1979. Natl Inst Health Consens Dev Conf Summ. 1979;2:65-8. Review. [Medline: 398969]

35. Koerner KR. The removal of impacted third molars. Principles and procedures. Dent Clin North Am. 1994 Apr;38(2):25578. Review. [Medline: $\underline{\text { 8206177] }}$

36. Bux P, Lisco V. Ectopic third molar associated with a dentigerous cyst in the subcondylar region: report of case. J Oral Maxillofac Surg. 1994 Jun;52(6):630-2. [Medline: 8189304] [doi: 10.1016/0278-2391(94)90105-8]

37. Medici A, Raho MT, Anghinoni M. Ectopic third molar in the condylar process: case report. Acta Biomed Ateneo Parmense. 2001;72(5-6):115-8. [Medline: 12233269]

38. Wassouf A, Eyrich G, Lebeda R, Grätz KW. Surgical removal of a dislocated lower third molar from the condyle region: case report. Schweiz Monatsschr Zahnmed. 2003;113(4):416-20. [Medline: 12768887]

39. Nageshwar. Comma incision for impacted mandibular third molars. J Oral Maxillofac Surg. 2002 Dec;60(12):1506-9. [Medline: 12465020] [doi: 10.1053/joms.2002.36152]

40. Susarla SM, Blaeser BF, Magalnick D. Third molar surgery and associated complications. Oral Maxillofac Surg Clin North Am. 2003 May;15(2):177-86. [Medline: 18088673] [doi: 10.1016/S1042-3699(02)00102-4]

41. Pippi R, Perfetti G. Lingual displacement of an entire lower third molar. Report of a case with suggestions for prevention and management. Minerva Stomatol. 2002 Jun;51(6):263-8. English, Italian. [Medline: 12147979]

42. Marciani RD. Complications of third molar surgery and their management. Atlas Oral Maxillofac Surg Clin North Am. 2012 Sep;20(2):233-51. [Medline: 23021398] [doi: 10.1016/j.cxom.2012.06.003]

43. Kim JW, Cha IH, Kim SJ, Kim MR. Which risk factors are associated with neurosensory deficits of inferior alveolar nerve after mandibular third molar extraction? J Oral Maxillofac Surg. 2012 Nov;70(11):2508-14. Epub 2012 Aug 15. [Medline: 22901857] [doi: 10.1016/j.joms.2012.06.004]

44. Renton T, Yilmaz Z, Gaballah K. Evaluation of trigeminal nerve injuries in relation to third molar surgery in a prospective patient cohort. Recommendations for prevention. Int J Oral Maxillofac Surg. 2012 Dec;41(12):1509-18. Epub 2012 Sep 25. [Medline: 23017786] [doi: 10.1016/j.ijom.2012.06.025]

45. Leung YY, Cheung LK. Correlation of radiographic signs, inferior dental nerve exposure, and deficit in third molar surgery. J Oral Maxillofac Surg. 2011 Jul;69(7):1873-9. Epub 2011 Mar 3. [Medline: 21371801] [doi: 10.1016/j.joms.2010.11.017].

46. Smith WP. The relative risk of neurosensory deficit following removal of mandibular third molar teeth: the influence of radiography and surgical technique. Oral Surg Oral Med Oral Pathol Oral Radiol. 2013 Jan;115(1):18-24. Epub 2012 Aug 22. [Medline: 22921833 ] [doi: $10.1016 / \mathrm{j} .0000 .2012 .03 .017$ ]

47. Umar G, Obisesan O, Bryant C, Rood JP. Elimination of permanent injuries to the inferior alveolar nerve following surgical intervention of the "high risk" third molar. Br J Oral Maxillofac Surg. 2013 Jun;51(4):353-7.Epub 2012 Sep 23. [Medline: 23010201] [doi: 10.1016/j.bjoms.2012.08.006]

48. Renton T, Hankins M, Sproate C, McGurk M. A randomised controlled clinical trial to compare the incidence of injury to the inferior alveolar nerve as a result of coronectomy and removal of mandibular third molars. Br J Oral Maxillofac Surg. 2005 Feb;43(1):7-12. [Medline: 15620767] [doi: 10.1016/j.bjoms.2004.09.002]

49. Blackburn CW, Bramley PA. Lingual nerve damage associated with the removal of lower third molars. Br Dent J. 1989 Aug 5;167(3):103-7. [Medline: 2765316] [doi: 10.1038/sj.bdj.4806922]

50. Hillerup S, Stoltze K. Lingual nerve injury in third molar surgery I. Observations on recovery of sensation with spontaneous healing. Int J Oral Maxillofac Surg. 2007 Oct;36(10):884-9. Epub 2007 Sep 4. [Medline: 17766086] [doi: 10.1016/j.ijom.2007.06.004]

51. Zuniga JR. Management of third molar-related nerve injuries: observe or treat? Alpha Omegan. 2009 Jun;102(2):79-84. [Medline: 19591333] [doi: 10.1016/j.aodf.2009.04.014]

52. Janakiraman EN, Alexander M, Sanjay P. Prospective analysis of frequency and contributing factors of nerve injuries following third-molar surgery. J Craniofac Surg. 2010 May;21(3):784-6. [Medline: 20485048] [doi: 10.1097/SCS.0b013e3181d7f29a]

53. Lata J, Tiwari AK. Incidence of lingual nerve paraesthesia following mandibular third molar surgery. Natl J Maxillofac Surg. 2011 Jul;2(2):137-40. [Medline: 22639500] [doi: 10.4103/0975-5950.94467]

54. Alhassani AA, AlGhamdi AS. Inferior alveolar nerve injury in implant dentistry: diagnosis, causes, prevention, and management. J Oral Implantol. 2010;36(5):401-7. Epub 2010 Jun 14. Review. [Medline: 20545547] [doi: 10.1563/AAID-JOI-D-09-00059]

55. Roy TS, Sarkar AK, Panicker HK. Variation in the origin of the inferior alveolar nerve. Clin Anat. 2002 Mar;15(2):143-7. [Medline: 11877794] [doi: 10.1002/ca.1110]

56. Ziccardi VB, Assael LA. Mechanisms of trigeminal nerve injuries. Atlas Oral Maxillofac Surg Clin North Am. 2001 Sep;9(2):1-11. [Medline: 11665372]

57. Bouloux GF, Steed MB, Perciaccante VJ. Complications of third molar surgery. Oral Maxillofac Surg Clin North Am. 2007 Feb;19(1):117-28, vii. Review. [Medline: 18088870]

58. Chuang SK, Perrott DH, Susarla SM, Dodson TB. Risk factors for inflammatory complications following third molar surgery in adults. J Oral Maxillofac Surg. 2008 Nov;66(11):2213-8. [Medline: 18940482] [doi: 10.1016/j.joms.2008.06.067] 
59. Winter G.B. Impacted mandibular third molars. St Louis: American Medical Book Co.; 1926. p. 241-79.

60. Pell GJ, Gregory BT. Impacted mandibular third molars: classification and modified techniques for removal. Dent Digest 1933;39:330-338.

61. García AG, Sampedro FG, Rey JG, Vila PG, Martin MS. Pell-Gregory classification is unreliable as a predictor of difficulty in extracting impacted lower third molars. Br J Oral Maxillofac Surg. 2000 Dec;38(6):585-587. [Medline: 11092770] [doi: 10.1054/bjom.2000.0535]

62. Almendros-Marqués N, Berini-Aytés L, Gay-Escoda C. Evaluation of intraexaminer and interexaminer agreement on classifying lower third molars according to the systems of Pell and Gregory and of Winter. J Oral Maxillofac Surg. 2008 May;66(5):893-9. [Medline: 18423277] [doi: 10.1016/j.joms.2007.09.011]

63. Carvalho RW, do Egito Vasconcelos BC. Assessment of factors associated with surgical difficulty during removal of impacted lower third molars. J Oral Maxillofac Surg. 2011 Nov;69(11):2714-21. Epub 2011 Jul 12. [Medline: 21752507] [doi: 10.1016/j.joms.2011.02.097]

64. Akadiri OA, Obiechina AE. Assessment of difficulty in third molar surgery--a systematic review. J Oral Maxillofac Surg. 2009 Apr;67(4):771-4. Review. [Medline: 19304033] [doi: 10.1016/j.joms.2008.08.010]

65. Carmichael FA, McGowan DA. Incidence of nerve damage following third molar removal: a West of Scotland Oral Surgery Research Group study. Br J Oral Maxillofac Surg. 1992 Apr;30(2):78-82. Review. [Medline: 1567807] [doi: 10.1016/0266-4356(92)90074-S]

66. Cheung LK, Leung YY, Chow LK, Wong MC, Chan EK, Fok YH. Incidence of neurosensory deficits and recovery after lower third molar surgery: a prospective clinical study of 4338 cases. Int J Oral Maxillofac Surg. 2010 Apr;39(4):320-6. Epub 2010 Jan 12. [Medline: 20061121] [doi: 10.1016/j.ijom.2009.11.010]

67. Hasegawa T, Ri S, Umeda M, Komori T. Multivariate relationships among risk factors and hypoesthesia of the lower lip after extraction of the mandibular third molar. Oral Surg Oral Med Oral Pathol Oral Radiol Endod. 2011 Jun;111(6):e1-7. [Medline: 21569985] [doi: 10.1016/j.tripleo.2011.02.013]

68. Jun SH, Kim CH, Ahn JS, Padwa BL, Kwon JJ. Anatomical differences in lower third molars visualized by 2D and 3D X-ray imaging: clinical outcomes after extraction. Int J Oral Maxillofac Surg. 2013 Apr;42(4):489-96. Epub 2013 Jan 24. [Medline: 23352698] [doi: 10.1016/j.ijom.2012.12.005]

69. Xu GZ, Yang C, Fan XD, Yu CQ, Cai XY, Wang Y, He D. Anatomic relationship between impacted third mandibular molar and the mandibular canal as the risk factor of inferior alveolar nerve injury. Br J Oral Maxillofac Surg. 2013 Feb 11. [Epub ahead of print] [Medline: 23411471] [doi: 10.1016/j.bjoms.2013.01.011]

70. Park W, Choi JW, Kim JY, Kim BC, Kim HJ, Lee SH. Cortical integrity of the inferior alveolar canal as a predictor of paresthesia after third-molar extraction. J Am Dent Assoc. 2010 Mar;141(3):271-8. [Medline: 20194382]

71. Ueda M, Nakamori K, Shiratori K, Igarashi T, Sasaki T, Anbo N, Kaneko T, Suzuki N, Dehari H, Sonoda T, Hiratsuka $\mathrm{H}$. Clinical significance of computed tomographic assessment and anatomic features of the inferior alveolar canal as risk factors for injury of the inferior alveolar nerve at third molar surgery. J Oral Maxillofac Surg. 2012 Mar;70(3):514-20. Epub 2011 Nov 12. [Medline: 22079065] [doi: 10.1016/j.joms.2011.08.021]

72. Leung YY, Cheung LK. Risk factors of neurosensory deficits in lower third molar surgery: an literature review of prospective studies. Int J Oral Maxillofac Surg. 2011 Jan;40(1):1-10. Epub 2010 Oct 28. Review. [Medline: 21035310] [doi: 10.1016/j.ijom.2010.09.005]

73. Chossegros C, Guyot L, Cheynet F, Belloni D, Blanc JL. Is lingual nerve protection necessary for lower third molar germectomy? A prospective study of 300 procedures. Int J Oral Maxillofac Surg. 2002 Dec;31(6):620-4. [Medline: 12521318] [doi: 10.1054/ijom.2002.0236]

74. Pogrel MA, Lee JS, Muff DF. Coronectomy: a technique to protect the inferior alveolar nerve. J Oral Maxillofac Surg. 2004 Dec;62(12):1447-52. [Medline: 15573343] [doi: 10.1016/j.joms.2004.08.003]

75. O'Riordan BC. Coronectomy (intentional partial odontectomy of lower third molars). Oral Surg Oral Med Oral Pathol Oral Radiol Endod. 2004 Sep;98(3):274-80. [Medline: 15356463] [doi: 10.1016/j.tripleo.2003.12.040]

\section{To cite this article:}

Juodzbalys G, Daugela P. Mandibular Third Molar Impaction: Review of Literature and a Proposal of a Classification.

J Oral Maxillofac Res 2013;4(2):e1

URL: http://www.ejomr.org/JOMR/archives/2013/2/e1/v4n2e1ht.pdf

doi: $10.5037 /$ jomr.2013.4201 
Copyright (C) Juodzbalys G, Daugela P. Accepted for publication in the JOURNAL OF ORAL \& MAXILLOFACIAL RESEARCH (http://www.ejomr.org), 11 June 2013.

This is an open-access article, first published in the JOURNAL OF ORAL \& MAXILLOFACIAL RESEARCH, distributed under the terms of the Creative Commons Attribution-Noncommercial-No Derivative Works 3.0 Unported License, which permits unrestricted non-commercial use, distribution, and reproduction in any medium, provided the original work and is properly cited. The copyright, license information and link to the original publication on (http://www.ejomr.org) must be included. 